chairmanship at ministerial level among member governments. The Council also meets regularly, under the chairmanship of the Secretary-General at the level of Permanent Representatives to OECD (ambassadors who head resident diplomatic missions). It is responsible for all questions of general policy and may establish subsidiary bodies as required to achieve the aims of the Organisation. Decisions and recommendations of the Council are adopted by consensus of all its members.

An Executive Committee, a Budget Committee and an External Relations Committee assist the Council although they have limited decision-making power within their fields of competence. In addition, the Executive Committee in Special Session meets, usually twice a year, and is attended by senior government officials. Most of the work of the OECD is prepared and carried out by about 250 specialized bodies (Committees, Working Parties, etc.). All members are normally represented on these bodies, except a few which have a more restricted membership. Delegates are usually officials from either the capitals of member states or the Permanent Delegations to the OECD. Funding is by member state contributions based on a formula related to their size and economy.

The International Energy Agency (IEA) and the Nuclear Energy Agency (NEA) are also part of the OECD system.

Headquarters: 2 rue André Pascal, 75775 Paris Cedex 16,

France.

Website: http://www.oecd.org

Secretary-General: Angel Gurría (Mexico).

Deputy Secretaries-General: Aart de Geus (Netherlands),

Pier Carlo Padoan (Italy), Mario Amano (Japan), Richard A.

Boucher (USA)

Publications include: OECD Factbook; Economic, Environmental and Social Statistics (annual); OECD Policy Briefs (20 a year); OECD Economic Surveys (by country); Environmental Performance Reviews (by country); OECD Economic Outlook (twice a year); Economic Policy Reform: Going for Growth (annual); OECD-FAO Agricultural Outlook (annual); Education at a Glance (annual); OECD Employment Outlook (annual); OECD Science, Technology and Industry Outlook (biennial); International Migration Outlook (annual); Health at a Glance (biennial); Society at a Glance (biennial); OECD Health Data (CD-ROM; annual); Financial Market Trends (twice a year); Statistics of International Trade (monthly); International Trade by Commodity Statistics (annual); Main Economic Indicators (monthly); Energy Balances (annual); World Energy Outlook (annual); National Accounts (quarterly and annual); African Economic Outlook (annual); OECD Observer (6 a year); Quarterly Labour Force Statistics; Model Tax Convention; Development Co-operation Report (annual); Development Centre Policy Briefs. For a full list of OECD publications, visit the website: http://www.oecdbookshop.org.

\section{Organization of the Islamic Conference (OIC)}

Founded in 1969, the objectives of the OIC are to promote Islamic solidarity among member states; to consolidate co-operation among member states in the economic, social, cultural, scientific and other vital fields of activities, and to carry out consultations among member states in international organizations; to endeavour to eliminate racial segregation, discrimination and to eradicate colonialism in all its forms; to take the necessary measures to support international peace and security founded on justice; to strengthen the struggle of all Muslim peoples with a view to safeguarding their dignity, independence and national rights; to create a suitable atmosphere for the promotion of co-operation and understanding among member states and other countries.

Members (57 as of Feb. 2010). Afghanistan, Albania, Algeria, Azerbaijan, Bahrain, Bangladesh, Benin, Brunei, Burkina
Faso, Cameroon, Chad, Comoros, Côte d'Ivoire, Djibouti, Egypt, Gabon, The Gambia, Guinea, Guinea-Bissau, Guyana, Indonesia, Iran, Iraq, Jordan, Kazakhstan, Kuwait, Kyrgyzstan, Lebanon, Libya, Malaysia, Maldives, Mali, Mauritania, Morocco, Mozambique, Niger, Nigeria, Oman, Pakistan, Palestine, Qatar, Saudi Arabia, Senegal, Sierra Leone, Somalia, Sudan, Suriname, Syria, Tajikistan, Togo, Tunisia, Turkey, Turkmenistan, Uganda, United Arab Emirates, Uzbekistan, Yemen. Observers. Bosnia and Herzegovina, Central African Republic, Russia, Thailand, Turkish Republic of Northern Cyprus.

Headquarters: PO Box 178, Jeddah 21411, Saudi Arabia. Website: http://www.oic-oci.org

Secretary-General: Dr Ekmeleddin İhsanoğlu (Turkey).

\section{Unrepresented Nations and Peoples Organization (UNPO)}

UNPO is an international organization created by nations and peoples around the world who are not represented in the world's principal international organizations, such as the UN. Founded in 1991, UNPO now has 69 members representing over $100 \mathrm{~m}$. people worldwide.

Membership. Open to all nations and peoples unrepresented, subject to adherence to the five principles which form the basis of UNPO's charter: equal right to self-determination of all nations and peoples; adherence to internationally accepted human rights standards; to the principles of democracy; promotion of nonviolence; and protection of the environment. Applicants must show that they constitute a 'nation or people' as defined in the Covenant.

Functions and Activities. UNPO offers an international forum for occupied nations, indigenous peoples, minorities and oppressed majorities, who struggle to regain their lost countries, preserve their cultural identities, protect their basic human and economic rights, and safeguard their environment.

It does not represent those peoples; rather it assists and empowers them to represent themselves more effectively. To this end, it provides professional services and facilities as well as education and training in the fields of diplomacy, human rights law, democratic processes, conflict resolution and environmental protection. Members, private foundations and voluntary contributions fund the Organization.

In total six former members of UNPO (Armenia, Belau, Estonia, Georgia, Latvia and Timor-Leste) subsequently achieved full independence and gained representation in the UN. Belau is now called Palau. Current members Bougainville and Kosovo have achieved a degree of political autonomy. Kosovo has declared itself an independent state, although both Serbia and Russia oppose its sovereignty.

Headquarters: Laan van Meerdervoort 70, 2517 AN The

Hague, Netherlands.

Website: http://www.unpo.org

General Secretary: Marino Busdachin (Italy).

Publication. UNPO News (quarterly).

\section{World Council of Churches}

The World Council of Churches was formally constituted on 23 Aug. 1948 in Amsterdam. In Feb. 2010 member churches numbered 349 from more than 110 countries. 